\title{
УДК 581.1
}

ЖУК О.I.

Інститут фізіології рослин і генетики НАН Украӥни,

Україна, м. Київ, 03022, вул. Васильківська, 31/17, e-mail: zhukollga@gmail.com, $+38(098) 824-24-17$

\section{ПРОДУКТИВНІСТЬ РОСЛИН ПШЕНИЦІ ОЗИМОЇ ЗА УМОВ ПОСУХИ}

Мета. Метою роботи було дослідження впливу грунтової посухи на продуктивність рослин пшениці озимої м'якої (Triticum aestivum L.). Memoдu. Рослини пшениці сортів Золотоколоса і Астарта вирощували в умовах оптимального живлення та зволоження до фази колосінняцвітіння, з початком якої дослідні рослини на 8 діб переводили у режим посухи, після чого відновлювали оптимальне водозабезпечення до завершення вегетації. Дозрілі рослини аналізували за структурою врожаю. Результати. Встановлено, що дія посухи у критичній фазі онтогенезу спричиняла зменшення висоти рослин, розмірів колоса, маси та числа зерен у ньому. При цьому озерненість рослин знижувалася більше у сорту Золотоколоса порівняно з сортом Астарта, особливо у бічних пагонах. Втрати маси зерен із колоса були нижчими у сорту Золотоколоса порівняно з сортом Астарта. Виснов$\boldsymbol{\kappa}$. Дефіцит води у грунті у критичній фазі колосіння-цвітіння призводив до зниження продуктивності рослин пшениці через інгібування росту, закладання і формування плодоелементів колоса, що залежало від специфіки сорту.

Ключові слова: Triticum aestivum L., пагін, колос, продуктивність, посуха.

Пшениця озима м'яка належить до цінних продовольчих культур і займає провідне місце серед зернових злаків в Україні та світі. Ї̈̈ продуктивність зумовлюється генетичним потенціалом сорту, забезпеченням водою та живленням, ураженням шкідниками та хворобами, умовами довкілля [1]. Внесок селекції визначають як один із головних чинників у вирішенні проблеми продовольчої безпеки [2, 3]. Підвищення продуктивності та якості зерна пшениці значною мірою базується на інтрогресивній гібридизації зі спорідненими родами і видами. У сортименті пшениці значна частка сортів несе генетичний матеріал жита. Набули поширення сорти пшениці м'якої з пшенично-житніми транслокаціями 1BL/1RS, 1AL/1RS, господарська цінність яких зумовлюється підвищеною стійкі- стю до хвороб, абіотичних стресів, що пов'язано 3 впливом короткого плеча хромосоми жита $1 \mathrm{R}$. Потенційна врожайність зерна сучасних сортів пшениці озимої інтенсивного типу досягає 11,0 14,0 т/га, але впровадження їх у виробництво забезпечує незначний ріст реальної середньої врожайності. Різниця між максимальною та мінімальною врожайністю за роками досягає 100$105 \%$. Генетичний потенціал сортів пшениці озимої у середньому використовується на 45\%, і лише в окремих господарствах України він реалізується на 85\% [1]. Посуху відносять до ключових факторів, які зменшують продуктивність злакових культур, у тому числі пшениці озимої [4]. Тривалі та інтенсивні посухи стали звичайним явищем в Україні, тому дослідження їх впливу на продуктивність, посухостійкість та пластичність сортів пшениці озимої інтенсивного типу залишається актуальною проблемою біологічної науки.

У процесі еволюції рослини сформувалися як прикріплені організми, що зумовило стратегії їх існування, які забезпечували виживання за мінливих умов довкілля, зокрема дефіциту доступної води у середовищі $[5,6]$. Частина видів завершує вегетацію та репродукцію до настання посухи, інші мінімізують витрати води збільшенням опору продихів, зменшенням листкової поверхні, стимуляцією надходження води за рахунок розростання кореневої системи, осмотичною регуляцією шляхом накопичення осмотично активних речовин, зростанням еластичності клітинних стінок, утворенням дрібних клітин $[7,8]$. Сигнал про дефіцит води у грунті клітини коренів сприймають за допомогою трансмембранного гістидинкіназного осмосенсора за участі $\mathrm{Ca}^{2+}$-залежних протеїнкіназ, який локалізований на зовнішній стороні плазмалеми $[4,8]$. Трансдукція сигналу відбувається за рахунок активації каскаду кіназ, які через фосфорилювання/дефосфорилювання білків включають транскрипційні фактори регуляції генної експресії для стимуляції відповідних захисних механізмів. Водночас у зоні розтягнення кореня

\section{${ }^{\circ}$ ЖУк О.I.}


підвищується концентрація абсцизової кислоти, яка транспортується ксилемою до пагонів і $\epsilon$ домінуючим регулятором рухів замикальних клітин продихів. До складу сигналу про зміну водного статусу, який надходить ксилемою, входять також цитокінін у формі зеатинрибозиду, етилен, мікроРНК, малат. Однією з основних відповідей листків рослин на посуху є закриття продихів, що одночасно 3 мінімізацією втрат води припиняє надходження вуглекислого газу $\mathrm{i}$ лімітує фотосинтетичний метаболізм, який $\epsilon$ джерелом вуглеводів для рослинного організму. Меристеми та насіння у період формування належать до головних атрагуючих центрів рослини і потребують постійного надходження відповідних ресурсів і енергії. Встановлено, що в умовах дефіциту води інгібується клітинний ріст, особливо його проліферативна складова в інтеркалярних та апікальних меристемах [9]. Затримка поділу клітин у період функціонування меристем належить до першочергових причин зменшення розмірів рослин, листкового апарату, генеративних органів за дії посухи, що відносять до головних причин втрат врожаю. Успіх репродукції та реалізації продуктивного потенціалу сорту значною мірою залежить від його чутливості до абіотичних стресів, загального росту та розвитку рослин, тривалості та ступеня втрати води, тургору, віку і стадії розвитку окремих органів, типу клітин та субклітинних компартментів $[4,8]$. Ефективний фотосинтез і накопичення резервів вуглеводів у стеблі пшениці у фазі колосіння-цвітіння відіграють вирішальну роль у процесах запилення та запліднення, формування ембріона і ендосперму, наливу зерна, що безпосередньо впливає на кінцевий врожай. Цей період онтогенезу відносять до найбільш чутливих до дії посухи через високу вразливість пилкових зерен, процесу проростання пилкової трубки, початкових етапів розвитку насінини [2]. У сучасних сортів інтенсивного типу з пшенично-житніми транслокаціями виявлено апікальне домінування 3 боку головного пагона, який забирає найбільше ресурсів рослини до завершення утворення репродуктивних органів і наливу зерна [10]. Водночас такі сорти забезпечують розвиток 5-8 продуктивних пагонів зі значною кількістю зерен у колосі, що дозволяє збільшити вихід зерна на одиницю площі посіву, зменшити норми висіву насіння і одночасно підвищує потреби у забезпеченні водою з грунту протягом усього онтогенезу.
Метою роботи було дослідження дії грунтової посухи у критичній фазі онтогенезу колосіння-цвітіння на продуктивність рослин пшениці озимої сортів інтенсивного типу.

\section{Матеріали і методи}

Рослини пшениці озимої м'якої (Triticum aestivum L.) сортів Золотоколоса (спільної селекції Інституту фізіології рослин і генетики НАН України i Миронівського інституту пшениці імені В.М. Ремесла НААН України) та Астарта (селекції Інституту фізіології рослин і генетики НАН України) вирощували в умовах вегетаційних дослідів на суміші грунту з піском у співвідношенні 4:1 у посудинах місткістю 7,5 кг. Живлення складало $\mathrm{N}_{160} \mathrm{P}_{160} \mathrm{~K}_{160}$ за діючою речовиною, його додавали за набивання посудин, а також у фазі виходу в трубку. Для підживлення використовували виготовлене промисловим способом добриво нітроамофоска зі збалансованим вмістом елементів мінерального живлення. Протягом періоду вирощування рослин відносну вологість грунту підтримували на рівні 70\% від повної вологоємкості (ПВ). У фазі колосіння-цвітіння рослини дослідних варіантів переводили на режим грунтової посухи шляхом зменшення норм поливу. Вологість грунту знижувалася до 30\% ПВ і підтримувалася на такому рівні протягом 8 діб, після чого відновлювалася до рівня контролю, який відповідав 70\% ПВ. Повторність досліду п'ятикратна. У кожній посудині вирощували по 15 рослин. Дозрілі рослини видаляли 3 посудин, висушували до повітряно-сухого стану і проводили аналіз структури врожаю, який передбачав виміри довжини пагонів, колоса, підрахунки кількості колосків і зерен у ньому, визначення маси зерен у колосі. Результати статистично оброблено 3 використанням програми Microsoft Excel.

\section{Результати та обговорення}

Дослідження дії грунтової посухи на рослини пшениці озимої сортів Астарта та Золотоколоса у критичній фазі онтогенезу колосінняцвітіння дозволило встановити, що наслідком тривалого дефіциту води була затримка росту пагонів у висоту (табл. 1). У цій фазі ще тривав інтенсивний ріст підколосового міжвузля, тому зменшення довжини пагона відбувалося саме за його рахунок. Кількість пагонів на рослину після дії посухи залишалася незмінною в обох сортів, а затримка їх росту була значнішою у сорту 
Золотоколоса порівняно 3 сортом Астарта, особливо у пагонів 2 та 3 порядку.

Рослини сорту Астарта, на відміну від сорту Золотоколоса, формували 5 пагонів, однак серед пагонів 4 порядку лише незначна частина була продуктивною. У рослин сорту Золотоколоса за дії посухи інгібування росту бічних пагонів було значнішим порівняно з сортом Астарта, а висота пагона 3 порядку зменшувалася більш ніж удвічі. У пшениці сорту Астарта ріст бічних пагонів пригнічувався слабше, однак висота головного пагона рослин дослідного та контрольного варіантів відрізнялася більше, ніж у сорту Золотоколоса. Колос пшениці сорту Астарта за оптимальних умов був більшим, ніж у сорту Золотоколоса (табл. 2).

Після дії посухи відзначено скорочення розміру колоса в обох сортів у пагонах усіх порядків. Дефіцит води у фазі колосіння-цвітіння пшениці не змінив кількості колосків у головному колосі в обох сортів, що свідчить про завершення його розвитку до початку дії стресу. Однак у колосах бічних пагонів виявлено зменшення кількості колосків, яке було найбільш значним у пагонах 3 порядку, особливо у сорту Золотоколоса, і зумовлювалося переважно їх редукцією у верхній і нижній частині колоса. Найбільш розвиненими були колоски центральної частини колоса.

Маса зерен у головному колосі пшениці сортів Астарта і Золотоколоса в оптимальних умовах була близькою (табл. 3).

Після дії посухи відзначено зменшення маси та кількості зерен у всіх колосах обох сортів пшениці. Однак стратегії формування продуктивності за обмеженого забезпечення водою у критичний період онтогенезу у цих сортів відрізнялися. У сорту Астарта у колосах після дії стресу було закладено більше зерен, але їх загальна маса була меншою порівняно з сортом 3олотоколоса. Найменше зерен у колосі 3 порядку виявлено у сорту Золотоколоса. Не усі колоски у цього сорту після дії стресу закладали зернівки, що могло бути зумовлено порушенням процесів запилення і запліднення, редукцією квіток та зачатків зернівок за дефіциту ресурсів.

Таким чином, дія грунтової посухи на рослини пшениці м'якої озимої сортів Астарта і Золотоколоса у фазі колосіння-цвітіння спричиняла інгібування ростових процесів у пагонах $\mathrm{i}$ колосах, зменшення кількості колосків у колоcax бічних пагонів, зниження чисельності та маси зерен у всіх колосах. В оптимальних умо- вах вирощування та після дії посухи в обох сортів пшениці було виявлено домінування головного пагона над бічними, що зумовлювалося відповідним перерозподілом асимілятів та інших ресурсів між ними. Реакція рослин на дефіцит води у грунті у критичний період онтогенезу у досліджених нами сортів відрізнялася. Сорт Астарта відзначався більш рівномірним розвитком продуктивних стебел, що дозволило сформувати у стресових умовах більшу кількість зерен порівняно з сортом Золотоколоса, який зменшив число дозрілих зернівок на рослину, особливо у колосах пагонів 2 та 3 порядків, але збільшив їх масу порівняно 3 сортом Астарта. Встановлено, що зазвичай не більше $60 \%$ квіток у пшеничному колосі формують зернівки, а дія стресових чинників здатна зменшувати їх кількість за рахунок порушення процесів запилення та запліднення, через втрату фертильності пилкових зерен, дефіцит ресурсів для повноцінного розвитку зародка і ендосперму [3, 4]. Зернівки у фазі наливу $є$ атрагуючими центрами, які збирають необхідні ресурси з усієї рослини. Обмеження водопостачання за умов посухи спричиняє перерозподіл асимілятів між пагонами в бік пріоритетного забезпечення головного колоса, що може призводити до редукції інших. Сучасні сорти пшениці м'якої Золотоколоса та Астарта містять інтрогресії генетичного матеріалу жита, які підвищують їх стійкість до посухи і безпосередньо впливають на реалізацію продуктивного потенціалу за нестабільних умов навколишнього середовища. Встановлена відмінність у реакції цих сортів на недостатнє забезпечення водою 3 грунту, яка полягала у зменшенні чисельності зерен у колосі зі збереженням їх маси у сорту Золотоколоса та утриманні високої озерненості колоса за рахунок меншої їх маси у сорту Астарта. Отримані результати дозволяють вважати, що більш пластичний сорт Астарта за обмеження водних ресурсів виявлятиме вищу насіннєву продуктивність на одиницю площі посіву порівняно з сортом Золотоколоса. Стратегії адаптації до посухи у цих сортів пшениці зумовлені генетично, що дозволяе цілеспрямоване їх вирощування у різних кліматичних зонах. Дослідження впливу грунтової посухи на рослини пшениці сортів інтенсивного типу у критичні для реалізації потенційної продуктивності періоди онтогенезу дозволяє 3'ясувати причини втрат врожаю у посіві й оцінити посухостійкість конкретних сортів. 
Таблиця 1. Довжина пагонів пшениці сортів Астарта і Золотоколоса в оптимальних умовах вирощування та за дії посухи

\begin{tabular}{|c|c|c|c|c|c|}
\hline \multirow{2}{*}{ Сорт, варіант } & \multicolumn{5}{|c|}{ Довжина пагона, мм. } \\
\cline { 2 - 6 } & $\begin{array}{c}\text { головний. } \\
\text { пагін }\end{array}$ & $\begin{array}{c}\text { пагін } \\
\text { порядку }\end{array}$ & $\begin{array}{c}\text { пагін } \\
\text { порядку }\end{array}$ & $\begin{array}{c}\text { пагін } \\
\text { 3 порядку }\end{array}$ & $\begin{array}{c}\text { пагін } \\
\text { 4 порядку }\end{array}$ \\
\hline Астарта, контроль & $759 \pm 9$ & $645 \pm 9$ & $397 \pm 12$ & $308 \pm 10$ & $193 \pm 12$ \\
\hline Астарта, посуха & $492 \pm 10$ & $441 \pm 11$ & $239 \pm 11$ & $199 \pm 10$ & $130 \pm 12$ \\
\hline Золотоколоса, контроль & $687 \pm 10$ & $608 \pm 9$ & $532 \pm 10$ & $524 \pm 11$ & - \\
\hline Золотоколоса, посуха & $465 \pm 9$ & $371 \pm 10$ & $302 \pm 12$ & $181 \pm 12$ & - \\
\hline
\end{tabular}

Таблиця 2. Довжина колоса та кількість колосків у колосі

\begin{tabular}{|c|c|c|c|c|c|c|c|c|}
\hline \multirow{2}{*}{ Сорт, варіант } & \multicolumn{4}{|c|}{ Довжина колоса, мм } & \multicolumn{3}{c|}{ Кількість колосків у колосі, шт. } \\
\cline { 2 - 9 } & гол. к. & б. к. 1 & 6. к. 2 & б. к. 3 & гол. к. & б. к. 1 & 6. к. 2 & б. к. 3 \\
\hline $\begin{array}{c}\text { Астарта, конт- } \\
\text { роль }\end{array}$ & $93 \pm 4$ & $81 \pm 3$ & $76 \pm 3$ & $70 \pm 4$ & $16 \pm 2$ & $14 \pm 2$ & $13 \pm 3$ & $12 \pm 3$ \\
\hline $\begin{array}{c}\text { Астарта, } \\
\text { посуха }\end{array}$ & $78 \pm 3$ & $68 \pm 5$ & $55 \pm 6$ & $50 \pm 4$ & $16 \pm 2$ & $13 \pm 4$ & $10 \pm 3$ & $9 \pm 3$ \\
\hline $\begin{array}{c}\text { Золотоколоса, } \\
\text { контроль }\end{array}$ & $84 \pm 5$ & $73 \pm 4$ & $70 \pm 5$ & $67 \pm 4$ & $13 \pm 3$ & $12 \pm 3$ & $12 \pm 3$ & $12 \pm 3$ \\
\hline $\begin{array}{c}\text { Золотоколоса, } \\
\text { посуха }\end{array}$ & $72 \pm 6$ & $62 \pm 5$ & $59 \pm 5$ & $50 \pm 4$ & $13 \pm 4$ & $12 \pm 3$ & $10 \pm 3$ & $8 \pm 4$ \\
\hline
\end{tabular}

Примітки: гол. к. - головний колос, б.к. - бічний колос.

Таблиця 3. Маса та кількість зерен у колосі пшениці

\begin{tabular}{|c|c|c|c|c|c|c|c|c|}
\hline \multirow{2}{*}{$\begin{array}{c}\text { Сорт, варі- } \\
\text { ант }\end{array}$} & \multicolumn{4}{|c|}{ Маса зерен у колосі, г } & \multicolumn{3}{c|}{ Кількість зерен у колосі, шт. } \\
\cline { 2 - 9 } & гол. к. & б. к. 1 & 6. к. 2 & 6. к.3 & гол. к. & б. к. 1 & б. к. 2 & б. к. 3 \\
\hline $\begin{array}{c}\text { Астарта, } \\
\text { контроль }\end{array}$ & $2,08 \pm 0,4$ & $1,27 \pm 0,3$ & $0,57 \pm 0,2$ & $0,35 \pm 0,2$ & $39 \pm 3$ & $25 \pm 2$ & $20 \pm 4$ & $15 \pm 3$ \\
\hline $\begin{array}{c}\text { Астарта } \\
\text { посуха }\end{array}$ & $1,35 \pm 0,2$ & $0,76 \pm 0,2$ & $0,41 \pm 0,1$ & $0,21 \pm 0,1$ & $34 \pm 3$ & $23 \pm 3$ & $15 \pm 3$ & $12 \pm 4$ \\
\hline $\begin{array}{c}\text { Золотоколо- } \\
\text { саконтроль }\end{array}$ & $1,94 \pm 0,5$ & $1,25 \pm 0,1$ & $0,79 \pm 0,2$ & $0,52 \pm 0,1$ & $38 \pm 3$ & $28 \pm 3$ & $20 \pm 4$ & $13 \pm 5$ \\
\hline $\begin{array}{c}\text { Золотоколо- } \\
\text { сапосуха }\end{array}$ & $1,36 \pm 0,2$ & $0,91 \pm 0,2$ & $0,58 \pm 0,2$ & $0,35 \pm 0,2$ & $34 \pm 3$ & $24 \pm 4$ & $11 \pm 4$ & $5 \pm 3$ \\
\hline
\end{tabular}

Примітки: гол. к. - головний колос; б.к. - бічний колос

\section{Висновки}

Встановлено, що дія грунтової посухи у критичній фазі колосіння-цвітіння на рослини озимої пшениці сортів Золотоколоса і Астарта спричиняла затримку росту пагонів, колосів, зменшення кількості та маси зерен у колосі. Зі збільшенням порядку пагона інгібування ростових процесів та насіннєвої продуктивності зростало більше у сорту Золотоколоса порівняно 3 сортом Астарта. Апікальне домінування головного пагона в умовах посухи посилювалося в обох сортів, однак більше у сорту Золотоколоса порівняно 3 сортом Астарта. Дія посухи не впливала на продуктивну кущистість рослин пшениці, що зумовлено завершенням формування відповідних структур пагона до ії початку. Втрати врожаю пшениці м'якої озимої за дефіциту води в грунті у фазі колосіння-цвітіння спричинені редукцією плодоелементів колоса через порушення процесів запилення та запліднення, розвитку ембріона та ендосперму і значною мірою залежать від індивідуальної пластичності та стійкості сорту.

\section{Література}

1. Васильківський С.П., Паустовський, В.М., Худолій О.Л. Проблема реалізації потенціалу продуктивності сучасних сортів озимої пшениці. Аграрні вісті. 2002. № 2. С. 6-8. 
2. Weng X., Wang L., Hu J., Du H., Xu C., Xing Y. Xiao J., Zhang Q. Grain number, plant height and heading date 7 is a central regulator of growth, development and stress response. Plant Physiol. 2014. Vol. 164. P. 735-747. doi: 10.1104/pp.113.231308.

3. Bancal P. Early development and enlargement of wheat floret primordial suggest a role of partitioning within spike to grain set. Field Crops Res. 2009. Vol. 110. P. 44-53. doi: 10.1016/j.fcr.2008.06.014.

4. Barnabas B., Jager K., Feher A. The effect of drought and heat stress on reproductive processes in cereals. Plant. Cell Environ. 2008. Vol. 31. P. 11-38. doi: 10.1111/j.1365-3040.2007.01727.x

5. Жук О.И. Адаптивная эволюция водного режима и засухоустойчивости растений. Фактори експериментальної еволюиї̈ організмів. 2010. Т. 8. С. 12-16.

6. Жук О.И. Эволюционная адаптация растений к существованию в условиях действия факторов биотической и абиотической природы. Фактори експериментальної еволюцї̈ організмів. 2011. Т. 11. С. 24-29.

7. Жук О.І. Транспорт води в рослинах. Вісник Харківського національного університету ім. В.Н. Каразіна. Серія біологія. 2010. Вип. 11, № 905. С. 212-217.

8. Жук О.І. Формування адаптивної відповіді рослин на дефіцит води. Физиология и биохимия культ. растений. 2011. T. 43, № 1. C. 26-37.

9. Жук О.І., Григорюк І.П., Гродзинський Д.М. Клітинний ріст рослин за умов водного стресу. Физиология и биохимия культ. растений.1999. 31, № 2. С. 83-93.

10. Жук О.І. Апікальне домінування в озимої пшениці. Фактори експериментальної еволюції організмів. 2017. Т. 21. C. $133-137$.

\section{References}

1. Vasilkivsky S.P., Paustovsky V.M., Chudoliy O.L. The problem of realization potential productivity of modern winter wheat cultivars. Agrarian news. 2002. № 2. P. 6-8. (In Ukrainian).

2. Weng X., Wang L., Hu J., Du H., Xu C., Xing Y. Xiao J., Zhang Q. Grain number, plant height and heading date 7 is a central regulator of growth, development and stress response. Plant Physiol. 2014. Vol. 164. P. 735-747. doi: 10.1104/pp.113.231308.

3. Bancal P. Early development and enlargement of wheat floret primordial suggest a role of partitioning within spike to grain set. Field Crops Res. 2009. Vol. 110. P. 44-53. doi:10.1016/j.fcr.2008.06.014.

4. Barnabas B., Jager K., Feher A. The effect of drought and heat stress on reproductive processes in cereals. Plant. Cell Environ. 2008. Vol. 31. P. 11-38. doi: 10.1111/j.1365-3040.2007.01727.x.

5. Zhuk O.I. Adaptive evolution of plant water regime and drought tolerance of plants. Factors in experimental evolution of organisms. 2010. Vol. 8. P. 12-16. (In Ukrainian)

6. Zhuk O.I. Plant adaptation evolution under biotic and abiotic conditions. Factors in experimental evolution of organisms. 2011. T. 11. C. 24-29. (In Ukrainian)

7. Zhuk O.I. Water transport in plants.The Journal of V.N. Karazin Kharkiv. Series: biology. 2010. Issue 11, № 905. P. $212-217$. (In Ukrainian)

8. Zhuk O.I. Formation of plant adaptive response on water deficit. Physiology and biochemistry of cultivated plants. 2011. Vol. 43, № 1. P. 26-37. (In Ukrainian)

9. Zhuk O.I., Grygorjuk I.P., Grodzinsky D.M. Cell plant growth under water stress. Physiology and biochemistry of cultivated plants. 1999. 31. № 2. C. 83-93. (In Ukrainian)

10. Zhuk O.I. The apical dominance in winter wheat Factors in experimental evolution of organisms. 2017. T. 21. C. 133-137. (In Ukrainian)

\section{ZHUK O.I.}

Institute of Plant Physiology and Genetics NAS Ukraine,

Ukraine, 03022, Kiev, Vasylkivska str., 31/17, e-mail: zhukollga@gmail.com

\section{PRODUCTIVITY OF WINTER WHEAT PLANTS UNDER DROUGHT}

Aim. The goal of research was to study the effects of soil drought on the productivity of winter wheat plants (Triticum aestivum L.). Methods. Wheat plants of the cultivars of Zolotocolosa and Astarta were grown under optimal nutrition and moisture to the earing-flowering phase. After the beginning of it the experimental plants were transferred to drought conditions for 8 days, after that the optimal water supply was restored to the end of the vegetation. The yield structure was analyzed in mature plants. Results. It is established that the effect of drought in the critical phase of ontogenesis led to a decrease in plant height, ear size, mass and number of grains in it. At the same time, the number of grains in ears of plants decreased more significantly in the cultivar Zolotocolosa compared to the Astarta, especially in the tillers. The loss of grains mass from the ear was lower in cultivar Zolotocolosa than to the Astarta. Conclusions. Water deficit in the soil in the critical phase of ear-flowering led to a decrease in the productivity of wheat plants due to the inhibition of growth, the laying and the formation elements of the ear and grains, that depended on the specificity of the cultivar. Keywords: Triticum aestivum L., stem, ear, productivity, drought. 